\title{
Effect of Kumura (Benincasa hispida) on the Physico-chemical and Storage Quality Characteristics of Duck Meat Loaves
}

\author{
J.K. Das ${ }^{1}$, M. Hazarika ${ }^{1}$, A. Das ${ }^{1}$, P. Gogoi ${ }^{1 *}$, P. Hussain ${ }^{2}$, \\ D.J. Kalita ${ }^{3}$ and N. Nahardeka ${ }^{4}$ \\ ${ }^{1}$ Department of Livestock Products Technology, \\ ${ }^{2}$ Department of VPH, ${ }^{3}$ Department of Vet, Biochemistry, C.V.Sc., A.A.U., Khanapara, \\ Guwahati, Assam, India \\ ${ }^{4}$ ICRP on Goat, Goat Research Station, Burnihat, Assam, India \\ *Corresponding author
}

\section{Keywords}

Duck meat loaves,

Kumura,

Moisture:protein,

Refrigerated

storage, TBARS, LDPE

Article Info

Accepted:

20 January 2019

Available Online:

10 February 2019

\section{A B S T R A C T}

The present study was undertaken to evaluate the effect of different levels of Kumura (Benincasa hispida) on the quality characteristics of duck meat loaves. The Kumura was incorporated at three different levels viz., 5, 7.5 and 10 percent replacing lean meat in the formulation. The products were analysed for various physicochemical and sensory attributes. $\mathrm{pH}$, crude protein, ether extract, and ash content of the products showed significantly decreasing trend with increasing levels of incorporation of Kumura. However, there was a significant increase in moisture, moisture to protein ratio and emulsion stability with increasing levels of incorporation of Kumura. Based on various parameters studied, $7.5 \%$ level of incorporation was optimized as the best. Duck meat loaves with optimum level of pumpkin along with control were aerobically packaged in LDPE pouches and assessed for storage quality under refrigerated $\left(4 \pm 1^{\circ} \mathrm{C}\right)$ conditions. The mean values of $\mathrm{pH}$ showed significantly increasing trend for both control as well as treatment samples whereas TBARS (mg malonaldehyde $/ \mathrm{kg}$ ) value, total plate count (log cfu/gm), total psychrophillic count showed significantly increasing trend with storage. Yeast and mould (log cfu/gm) count were not detected on first and fifth day of storage. However they were found on tenth day of storage. Thus, the kumura incorporated duck meat loaves could be successfully stored for a period 4 days at refrigeration temperature $\left(4 \pm 1^{0} \mathrm{C}\right)$ without any significant loss in quality.

\section{Introduction}

Duck constitutes about $10 \%$ of total poultry population occupying second place to chicken in India. Duck raising is a lucrative avocation among the poultry farmers of Assam. With a population of 4.72 million ducks, Assam ranks second in the Indian duck population which is about 27.43 million (Livestock census, 2012). Duck farming is found to be an effective tool for socio-economic development among the weaker sections of 
rural masses which provides supplementary and steady income besides providing much needed animal protein from duck eggs and meat. Duck raising is well suited to Assam because of presence of many water bodies, marshy river sides, wetlands and barren moors. Assam is producing around 16.65 tonnes of duck meat in the state annually (Economic survey of Assam, 2013).

Duck meat is a popular food of animal origin in Assam and it is consumed traditionally since time immemorial. Out of five distinct popular strains of duck namely Nageswari, Khaki Campbell, Cinahanh (Muscouvy), Rajhanh and Pati, Pati duck meat is the most common (Mahanta et al., 2001) among the rural consumers. There is no religious and social taboo in consumption of duck meat in Assam. Although majority of the poultry meat in Assam is contributed by chicken, duck meat is also gaining popularity due to its certain unique nutritional characteristics. Duck meat has combined characteristics of red meat and white meat i.e., it contains high level of phospholipids, precursors of aromas and high level of monounsaturated fatty acids especially oleic acid and linolenic acids (George T. et al., 2014) which constitute about $60 \%$ of total fatty acids. With recommendations for the reduction of red meat intake due to its association with cardiovascular diseases, the consumption of white meat and duck meat is gaining more attention.

Although meat processing has several advantages, but duck meat sector has not gained that momentum as compared to chicken. Processing of tough duck meat in comminuted value added meat products may offer better to utilize the ducks thereby paving a way to get better returns to the producers. Thus economically viable, nutritionally and organoleptically acceptable value added meat products can be developed utilizing duck meat. Reports indicate that some of the tribal communities have been preparing certain duck meat products with different herbs elsewhere in North Eastern Region (Hazarika et al., 2014). During festive season particularly during Magh Bihu, there is a tradition of preparing culinary products such as duck meat with Kumura in Assam which is relished by all people as a sign of happiness and satisfaction. Even duck meat with Kumura dishes are very popular in the hotels of Assam and are sold at a higher price.

'Kumura' which is also commonly known as winter melon, ash gourd, white pumpkin, wax gourd or Chinese water melon belongs to Cucurbitaceae family and is naturally acidic (Fatariah et al., 2015). It is a native of Japan and Java, however it is cultivated more or less throughout India and warm countries. It is a popular vegetable especially among Asian communities both for nutrition and medicinal purposes. It is prepared as a cooked vegetable, boiled with meat or included in a variety of dishes. The major constituents of Kumura are volatile oils, flavonoids, glycosides, saccharides, proteins, carotenes, vitamins, minerals, $\beta$ - stosterin and uronic acid. It is medicinally used in various complains such as gastrointestinal problems, respiratory diseases, hear diseases, diabetes mellitus and urinary diseases. It was traditionally used as a laxative, diuretic, tonic, aphrodisiac, cardiotonic and to prevent urinary caliculi, blood disease, insanity, epilepsy, schizophrenia, jaundice, dyspepsia, fever and is also used as antioxidant, anti-inflammatory, analgesic, anti-asthmatic, diuretic, nephroprotective, antidiabetic, hypolipidemic and as antimicrobial (Al-Snafi, 2013).

Keeping in view all the above facts, the present study was envisaged to attempt the still inconclusive studies on utilization of Kumura in the development of duck meat loaves at different levels to evaluate its effect 
on physicochemical properties and sensory profile and also to assess the storage quality of the developed products.

\section{Materials and Methods}

\section{Duck meat}

Local Pati ducks of age group 9-12 months irrespective of their sex was procured from the Goat Research Station (GRS), Burnihat. These live ducks were slaughtered by the halal method in the semi-mechanised poultry dressing unit of the Department of Livestock Products Technology, College of Veterinary Science, Khanapara, Guwahati-22 under strict hygienic condition. The body fat was trimmed and deboning of dressed ducks was done manually by removing all the tendons and separable connective tissue. The liver, heart, gizzard, skin and visceral fat were removed and packed separately in polythene bags at freezing temperature $\left(-18 \pm 2^{\circ} \mathrm{C}\right)$ until used. The deboned meat was also packed and stored similarly.

Duck fat was melted to liquid state for better emulsion formation.

Spices and condiments mixture

Condiments used were onion, garlic and ginger in a ratio of $3: 2: 1$ and grounded to a fine paste.

The spice mixture consisted of Dhania, Black pepper, jeera, red chilli powder, green chilli powder and kashmiri mirch powder.

\section{Kumura (Benincasa hispida)}

Young and tender Kumura was purchased from the local market, washed, peeled and then cut into small pieces. The pieces were finely minced in a mixer grinder and incorporated @ 0\%,5\%,7.5\% and 10\% in the formulation by replacing the lean meat.

\section{Preparation of emulsion}

The standardized formula for the preparation of emulsion for kumura incorporated duck loaves is presented in Table 1. Lean meat from dressed duck was cut into smaller chunks and ground in a mincer through $4 \mathrm{~mm}$ (pore size) plate. Meat emulsion was prepared in bowl chopper. Minced meat was blended with salt, sodium nitrite for 1.5 minutes.

Water in the form of crushed ice was added and blending continued for 1 minute. This was followed by the addition of cooked and filtered duck fat in liquid form and blended for another 1-2 minutes. This was followed by the addition of spice mixture, condiments, minced Kumura (Benincasa hispida) and other necessary ingredients and again blended for 1-2 minutes to get the desired emulsion.

\section{Stuffing and cooking}

The emulsion was filled into the rectangular stainless steel boxes under strict hygienic condition. Preliminary trials were conducted to optimize the processing conditions for the preparation of duck meat loaves.

The raw sausages were cooked at a specific time-temperature combination i.e., $85^{\circ} \mathrm{C}$ $\left(72^{\circ} \mathrm{C}\right.$ - core temperature) for $45 \mathrm{mins}$. The internal temperature of duck meat loaves was monitored by a thermometer while cooking.

\section{Packaging}

Thereafter the stainless steel moulds were taken out and then cooled down with chilled water and kept overnight at refrigeration temperature $\left(4 \pm 1^{0} \mathrm{C}\right)$ for chilling. Next day chilled blocks were taken out from the moulds and meat blocks were sliced manually into suitable shapes and packaged into LDPE bags. 


\section{Storage of packaged duck meat loaves}

The packaged duck meat loaves were stored under refrigeration temperature $\left(4 \pm 1^{0} \mathrm{C}\right)$ and then subjected to quality evaluation traits on first, fifth and tenth day of storage.

\section{Analytical procedures}

Cooking loss: The weight of each duck meat loaf was recorded before and after cooking. The weight loss during cooking process was termed as 'cooking loss' and was expressed as the percent loss in weight to the pre-cooked weight (Singh, 1996)

\section{pH}

The $\mathrm{pH}$ was determined as per the method of Pippen et al., (1965) by using a Metrohm 780 $\mathrm{pH}$ meter.

\section{Proximate analysis}

Moisture, crude protein, crude fat and ash contents in both treatment samples and control were determined by using standard procedures prescribed by A.O.A.C (1990).

\section{Moisture: Protein}

It was calculated after determining the moisture and protein contents of the samples.

\section{Emulsion stability}

Emulsion stability was determined as per the method put forwarded by Mongale et al., 1985.

\section{Thiobarbituric acid reacting substances (TBARS) value}

The TBARS value of the cooked products during storage was determined using the method described by Witte et al., (1970).

\section{Water holding capacity (WHC)}

WHC of loaf samples were evaluated according to the method as described by Wardlaw et al., (1973)

\section{Microbiological profile}

Total viable mesophillic bacterial count, total psychrophillic count and yeast and mould count was determined as per the procedure laid down in APHA, 1966 and ICMSF, 1978.

\section{Sensory evaluation}

The sensory evaluation of the products was carried out for various attributes namely colour, flavour juiciness, tenderness, texture and overall acceptability by the members of a semi trained panel on a 9 point hedonic scale wherein 9 denoted "extremely desirable" and 0 denoted "extremely undesirable"(Bratzler, 1971).

\section{Statistical analysis}

Data obtained in the study were analysed statistically on "SPSS-16.0" software package as per standard methods (Snedecor and Cochran, 1994). Five batches of the products were prepared and used as replicates in this study.

The permission for use of poultry birds i.e., ducks for the research purpose was taken from Institutional Animals Ethics Committee (IAEC), AAU, Khanapara, Guwahati, Assam.

\section{Results and Discussion}

\section{Physicochemical characteristics}

The mean values of various physicochemical properties namely $\mathrm{pH}$, cooking loss, emulsion stability, water holding capacity and proximate composition of the control and 
treated duck meat loaves incorporated with 0 , 5, 7.5 and 10 percent levels of Kumura (Benincasa hispida) are presented in Table 2.

\section{pH}

The study revealed a decreasing trend in $\mathrm{pH}$ values of Kumura incorporated duck meat loaves in the treated formulations. The increasing level of Kumura and decreasing trend in $\mathrm{pH}$ in the products might be due to the presence of phytochemicals including ascorbic acid (anti-oxidant) in Kumura. Fatariah et al., (2015) reported that Kumura is basically an acidic vegetable. Reddy et al., (2015) also reported that chicken meat patties incorporated with tomato paste @ 55\% had significantly lower values for $\mathrm{pH}$ due to acidic and anti-oxidant property of tomato. Similarly, Kaur et al., (2015b.) reported that an increase in the level of incorporation of the grape seed extract in chicken nuggets offered similar results.

\section{Cooking loss}

Duck meat loaves containing 10\% Kumura $\left(\mathrm{T}_{3}\right)$ recorded higher cooking loss which was non-significant $(\mathrm{P}>0.05)$ in comparison to other three formulations viz control $(0 \%$ Kumura), $\quad \mathrm{T}_{1} \quad(5 \%$ Kumura $)$ and $\mathrm{T}_{2}$ (7.5\% Kumura). This might be due to higher amount of moisture present in Kumura that was lost during cooking. The present findings correlated well with the report of Zargar et al., (2014) who studied the cooking losses of pumpkin incorporated chicken sausages at 4 different levels viz., 0, 6, 12 and 18 percent replacing the meat in the formulation.

Other Kumura incorporated sample also showed similar trend indicating its influence on cooking loss. To retain higher water in the products and to achieve lower cooking loss, time- temperature needs to be changed in time.

\section{Emusion stability}

Duck meat loaves containing 10\% Kumura $\left(\mathrm{T}_{3}\right)$ recorded significantly higher $(\mathrm{P}<0.01)$ in comparison to other three formulation viz., control (0\% Kumura), $\mathrm{T}_{1}$ (5\% Kumura) and $\mathrm{T}_{2}(7.5 \%$ Kumura). This might be due to contribution of proper amount of water by Kumura which was required to form a better emulsion. The present findings supported the findings of Bhosle et al., (2011) who studied emulsion stability of chicken meat nuggets incorporated with ground raw carrot $(0 \%, 5 \%$, $10 \%$ and $15 \% \%$ ) and mashed sweet potato $(0 \%, 5 \%, 10 \%$ and $15 \%)$ as functional ingredients.

The other two samples with Kumura also behaved in similar way and comparatively higher emulsion stability was recorded. The findings show an encouraging result and may be exploited in future studies.

\section{Proximate composition}

\section{Moisture}

The mean percent moisture content recorded for duck meat loaves incorporated with Kumura increased significantly $(\mathrm{P}<0.01)$ from the control $(63.32 \pm 0.84)$ to $\mathrm{T}_{1}(65.70 \pm 0.79)$, $\mathrm{T}_{2}(67.48 \pm 0.78)$ and $\mathrm{T}_{3}(69.14 \pm 0.85)$. This increase in moisture percent of Kumura might be due to higher amount of moisture present in Kumura.

A significant increase in moisture content was also reported by Zargar et al., (2014) who prepared chicken sausages with increase in level of pumpkin incorporation.

\section{Crude protein}

The mean crude protein content recorded for duck meat loaves incorporated with Kumura decreased significantly $(\mathrm{P}<0.01)$ from the 
control $(18.47 \pm 0.47)$ to $\mathrm{T}_{1}(16.77 \pm 0.48), \mathrm{T}_{2}$ $(15.48 \pm 0.48)$ and $\mathrm{T}_{3} \quad(14.05 \pm 0.47)$. This decrease in percent protein content may be attributed to comparatively lower protein contents of Kumura.

A significant decrease in protein content was also reported by Zargar et al., (2014) who prepared chicken sausages with increase in level of pumpkin incorporation.

\section{Crude fat/Ether extract(EE)}

The percent EE content in duck meat loaves revealed significantly $(\mathrm{P}<0.01)$ decreasing trend from the control to the treated formulations. The $\mathrm{EE}$ content was highest in the control product and lowest in $\mathrm{T}_{3}$ formulation. Such significant $(\mathrm{P}<0.01)$ differences in EE content between the control and amongst the treated products might be due to very low content of fat in Kumura.

Zargar et al., (2014) also recorded a decrease in ether extract content with increase in level of pumpkin incorporated chicken sausages because of low content of fat in pumpkin. The findings of the present study open up an avenue to develop fat reduce functional meat foods in future.

\section{Total Ash (TA)}

The study revealed significant differences in percent total ash values between control and treated samples. A lower TA percent was recorded in treated products having lowest content in $T_{3}$ and highest in $T_{1}$ formulation. A significantly higher percent TA was recorded in control formulation. The decrease TA content from the control to treated formulations as observed in the study are well in agreement with the findings of Zargar et al.,(2014) who studied the effects of incorporation of different levels of pumpkin in the chicken sausages.
Para et al., (2014) also reported similar results of decreased total ash content in Indian jujube pulp incorporated chicken sausages at $0 \%$, $5 \%, 10 \%$ and $15 \%$ level and recorded significantly $(\mathrm{P}<0.05)$ lower $\mathrm{TA}$ content in the chicken sausages prepared with the incorporation of $15 \%$ Indian jujube pulp.

Kaur et al., (2015a.) also found a decrease in total ash content with incorporation of $10 \%$ Daucus carota during development of a functional meat product (chicken nuggets).

\section{Moisture to protein ratio}

The study revealed a significantly increasing trend in moisture:protein (M:P) values from the control to the treated formulations. The $\mathrm{M}: \mathrm{P}$ was lowest in the control product and highest in the $T_{3}$ formulation. This is certainly due to the incorporation of Kumura at 4 different levels $(0 \%, 5 \%, 7.5 \%$ and $10 \%)$ in the duck meat loaves which imparted high moisture: protein attributes. The results correlated well with the findings of Verma $e t$ al., 2015 who prepared chicken meat patties by using pumpkin pulp and recorded high moisture:protein ratio with $30 \%$ incorporation sample. Normally a lower moisture protein ratio is preferred from nutritional point of view. Ten percent incorporation is not therefore advisable.

\section{Water holding capacity}

The mean WHC recorded for duck meat loaves prepared by using 4 different formulation revealed that there was gradual and significant $(\mathrm{P}<0.01)$ increasing trend of WHC from the control formulation to $\mathrm{T}_{3}$ formulation on first day. The higher WHC of the duck meat loaves might be due to good and stable loaf formation by the kumura incorporated samples.

No significant $(\mathrm{P}>0.05)$ effect of Kumura was observed on the colour scores of the control 
and the treated duck meat loaves due to the incorporation of kumura indicating that the panellists could not differentiate the variation in colour among the samples.

In terms of flavour, no-significant differences were revealed in the duck meat loaves. But highest score was given to the control samples. Incorporation of Kumura in the duck meat loaves is acceptable from flavour point of view. Similarly, Mendiratta et al., (2008) also reported that flavour scores were higher in seasonal vegetables incorporated emulsion based chicken nuggets.

The observations on juiciness scores revealed no-significant differences of duck meat loaves due to incorporation of Kumura. The panelists offered almost equal scores for juiciness for all products which indicated that Kumura incorporation in duck meat loaves does not affect juiciness.

Tenderness values also revealed nosignificant differences in the Kumura incorporated duck meat loaves. Since meat loaf is a comminuted emulsion based product and kumura was used in paste form, it did not affect the tenderness which the panelists therefore could not differentiate this sensory quality. Samples treated with $7.5 \%$ Kumura $\left(\mathrm{T}_{2}\right)$ showed a higher value as compared to the control, $T_{1}$ and $T_{3}$ samples. However, it was found that there were no significant differences between control and treated samples (Table 3).

The study on textural characteristics revealed no-significant differences in the overall acceptability of duck meat loaves due to incorporation of Kumura. The panelists offered almost equal score for all the products. In the study, no major textural changes were recorded with the use of Kumura in duck meat loaves.
The study revealed no significant differences in the overall acceptability of duck meat loaves due to incorporation of Kumura. The treated samples were equally accepted like the control one, however slight higher score was offered for the control product. The study revealed that Kumura can be used to prepare duck meat loaf.

\section{Storage life studies}

The shelf life of the kumura incorporated duck meat loaves were determined by different physicochemical, microbiological studies on $1^{\text {st }}, 5^{\text {th }}$ and $10^{\text {th }}$ day of storage.

\section{Physicochemical characteristics}

The mean values of $\mathrm{pH}$ and thiobarbituric acid reacting substances (TBARS) of aerobically packaged cooked duck meat loaves incorporated with 0 (Control), $5\left(\mathrm{~T}_{1}\right)$, $7.5\left(\mathrm{~T}_{2}\right)$ and $10\left(\mathrm{~T}_{3}\right)$ percent levels of Kumura during refrigerated storage $\left(4 \pm 1^{0} \mathrm{C}\right)$ are presented in Table 4.

\section{pH}

Storage life studies revealed that the treated and control groups showed a significantly $(\mathrm{P}<0.01)$ increasing trend in $\mathrm{pH}$ values from $1^{\text {st }}$ day to $10^{\text {th }}$ day. The gradual increase in $\mathrm{pH}$ values during storage might be due to the release of alkaline metabolites in the end products which might be produced by the higher growth of microbes. Reddy et al., (2015) also reported that an increase value of $\mathrm{pH}$ in chicken meat patties on storage was related with the increase of microbial load.

\section{Thiobarbituric acid reacting substances} (TBARS)

TBARS value showed an increasing trend along with the increase in storage periods irrespective of the control and treated 
formulations. Increase in the TBA values during storage might be due to the lipid oxidation as a result of higher microbial load. Zargar et al., (2014) reported that TBARS value increased significantly in pumpkin incorporated chicken sausages at longer storage period. He also reported that TBA (mg malonalehyde/ $\mathrm{kg}$ ) value showed significantly $(\mathrm{P}<0.05)$ increasing trend with storage and TBA values decreased with increase incorporation of pumpkin.

Microbiological characteristics: The mean values of various microbiological parameters namely Total Viable Mesophillic Bacterial Count (TVMBC), Total Psychrophillic count, Yeast and Mould counts of aerobically packaged cooked duck meat loaves incorporated with $0,5,7.5$ and 10 percent levels of kumura during refrigerated storage $\left(4 \pm 1^{0} \mathrm{C}\right)$ are presented in Table 5 .

The TVMBC of the kumura incorporated (treated) duck meat loaves and the control groups recorded an increasing trend from $1^{\text {st }}$ day to $10^{\text {th }}$ day which was statistically significant $(\mathrm{P}<0.01)$. This might be due to easy availability of the nutrients and more favourable conditions for microbial growth. The findings revealed the fact that incorporation of kumura at an increasing percentage put a hurdle and restricted the growth of microbes because of its inherent biochemical properties. The present findings correlated well with the report of Zargar et al., (2014) who also reported a significant $(\mathrm{P}<0.01)$ increase in the TVMBC in pumpkin incorporated chicken sausages at prolonged storage period.

The total psychrophilic count in duck meat loaves recorded an increasing trend from $1^{\text {st }}$ day to $10^{\text {th }}$ day of storage which was statistically significant $(\mathrm{P}<0.01)$. This might be due to easy availability of the nutrients and more favourable conditions for microbial growth. The present findings correlated well with the report of Zargar et al., (2014) who also reported a significant $(\mathrm{P}<0.01)$ increase in the total psychrophilic count in pumpkin incorporated chicken sausages.

Table.1 Formula for preparation of Duck meat loaves

\begin{tabular}{|c|l|c|c|c|c|}
\hline $\begin{array}{c}\text { Sl } \\
\text { No. }\end{array}$ & \multicolumn{1}{|c|}{ Ingredients } & $\mathbf{C}(\mathbf{\%})$ & $\mathbf{T}_{\mathbf{1}}(\mathbf{\%})$ & $\mathbf{T}_{\mathbf{2}}(\mathbf{\%})$ & $\mathbf{T}_{\mathbf{3}}(\mathbf{\%})$ \\
\hline $\mathbf{1 .}$ & Minced duck meat & 78 & 73 & 70.5 & 68 \\
\hline $\mathbf{2 .}$ & Duck fat & 10 & 10 & 10 & 10 \\
\hline $\mathbf{3 .}$ & Kumura & 0 & 5 & 7.5 & 10 \\
\hline $\mathbf{4 .}$ & Spices and condiments & 4 & 4 & 4 & 4 \\
\hline $\mathbf{5 .}$ & Egg white & 1.18 & 1.18 & 1.18 & 1.18 \\
\hline $\mathbf{6 .}$ & Ice cubes & 5 & 5 & 5 & 5 \\
\hline $\mathbf{7 .}$ & Salt & 1.5 & 1.5 & 1.5 & 1.5 \\
\hline $\mathbf{8 .}$ & Sodium nitrite & 0.02 & 0.02 & 0.02 & 0.02 \\
\hline $\mathbf{9 .}$ & Wheat flour & 0.3 & 0.3 & 0.3 & 0.3 \\
\hline
\end{tabular}


Table.2 Effect of kumura on $\mathrm{pH}$, cooking loss, emulsion stability, water holding capacity, proximate composition and moisture:protein of duck meat loaves (Mean \pm S.E)

\begin{tabular}{|l|c|c|c|c|}
\hline \multicolumn{1}{|c|}{ Parameters } & \multicolumn{3}{c|}{} \\
\cline { 2 - 5 } & Control & T1 & T2 & T3 \\
\hline pH & $5.99 \pm 0.03$ & $5.87 \pm 0.02$ & $5.77 \pm 0.03$ & $5.71 \pm 0.03$ \\
\hline Cooking loss (\%) & $6.20 \pm 0.59$ & $7.31 \pm 0.84$ & $8.63 \pm 0.96$ & $9.63 \pm 1.06$ \\
\hline Emusion stability (\%) & $2.44 \pm 0.11^{\mathrm{A}}$ & $1.70 \pm 0.08^{\mathrm{B}}$ & $1.50 \pm 0.09^{\mathrm{BC}}$ & $1.30 \pm 0.01^{\mathrm{C}}$ \\
\hline Moisture (\%) & $63.32 \pm 0.84^{\mathrm{C}}$ & $65.70 \pm 0.79^{\mathrm{BC}}$ & $67.48 \pm 0.78^{\mathrm{AB}}$ & $69.14 \pm 0.85^{\mathrm{A}}$ \\
\hline Crude protein (\%) & $18.47 \pm 0.40^{\mathrm{A}}$ & $16.77 \pm 0.48^{\mathrm{B}}$ & $15.48 \pm 0.48^{\mathrm{B}}$ & $14.05 \pm 0.47^{\mathrm{C}}$ \\
\hline Crude Fat (\%) & $13.41 \pm 0.11^{\mathrm{A}}$ & $13.06 \pm 0.06^{\mathrm{A}}$ & $12.08 \pm 0.20^{\mathrm{B}}$ & $11.27 \pm 0.17^{\mathrm{C}}$ \\
\hline Total Ash (\%) & $2.25 \pm 0.15^{\mathrm{A}}$ & $1.85 \pm 0.12^{\mathrm{B}}$ & $1.51 \pm 0.13^{\mathrm{BC}}$ & $1.23 \pm 0.11^{\mathrm{C}}$ \\
\hline Moisture:Protein & $3.43 \pm 0.10^{\mathrm{C}}$ & $3.93 \pm 0.14^{\mathrm{B}}$ & $4.37 \pm 0.16^{\mathrm{B}}$ & $4.94 \pm 0.19^{\mathrm{A}}$ \\
\hline WHC & $43.91 \pm 1.20$ & $48.57 \pm 1.44$ & $55.55 \pm 1.52$ & $61.15 \pm 1.53$ \\
\hline
\end{tabular}

$\mathrm{n}=5$

Mean in row bearing a common superscript (capital letter) do not differ significantly $(\mathrm{P}<0.01)$

Table.3 Effect of Kumura (Benincasa hispida) on sensory attributes of duck meat loaves $($ Mean \pm SE)

\begin{tabular}{|l|c|c|c|c|}
\hline Sensory attributes & Control $(\mathbf{0 \%})$ & $\mathbf{T}_{\mathbf{1}} \mathbf{( 5 \% )}$ & \multicolumn{1}{|c|}{$\mathbf{T}_{\mathbf{2}} \mathbf{( 7 . 5 \% )}$} & $\mathbf{T}_{\mathbf{3}} \mathbf{( 1 0 \% )}$ \\
\hline Colour & $7.50 \pm 0.13$ & $7.33 \pm 0.16$ & $7.25 \pm 0.16$ & $7.50 \pm 0.17$ \\
\hline Flavour & $7.36 \pm 0.17$ & $7.00 \pm 0.21$ & $7.21 \pm 0.19$ & $7.31 \pm 0.19$ \\
\hline Juiciness & $7.21 \pm 0.18$ & $7.13 \pm 0.19$ & $7.48 \pm 0.17$ & $7.36 \pm 0.18$ \\
\hline Tenderness & $7.26 \pm 0.15$ & $7.20 \pm 0.14$ & $7.40 \pm 0.15$ & $7.23 \pm 0.17$ \\
\hline Texture & $7.03 \pm 0.16$ & $6.96 \pm 0.16$ & $7.03 \pm 0.20$ & $6.96 \pm 0.21$ \\
\hline Overall acceptability & $7.38 \pm 0.13$ & $7.15 \pm 0.14$ & $7.36 \pm 0.15$ & $7.33 \pm 0.17$ \\
\hline
\end{tabular}

$\mathrm{n}=5$

Table.4 Effect of refrigerated storage on $\mathrm{pH}$, thiobarbituric acid reacting substances (TBARS) value of aerobically packaged cooked duck meat loaves (Mean \pm SE)

\begin{tabular}{|c|c|c|c|c|}
\hline \multirow{2}{*}{$\begin{array}{l}\text { Physico-chemical } \\
\text { attributes }\end{array}$} & \multirow[t]{2}{*}{ Treatments } & \multicolumn{3}{|c|}{ Storage period (days) } \\
\hline & & 1 & 5 & 10 \\
\hline \multirow[t]{4}{*}{ pH } & Control (0\%) & $5.86 \pm 0.04^{\mathrm{A}}$ & $55.99 \pm 0.04^{\mathrm{A}}$ & ${ }_{c} 6.13 \pm 0.03^{A}$ \\
\hline & $\mathrm{T} 1(5 \%)$ & $\mathrm{a}^{5} .77 \pm 0.02^{\mathrm{AB}}$ & ${ }_{b} 5.86 \pm 0.02^{\mathrm{AB}}$ & $c^{5.99} \pm 0.03^{\mathrm{B}}$ \\
\hline & $\mathrm{T} 2(7.5 \%)$ & $\mathrm{a}^{5} .66 \pm 0.04^{\mathrm{BC}}$ & ${ }_{b} 5.77 \pm 0.04^{\mathrm{BC}}$ & ${ }^{c} 5.90 \pm 0.05^{\mathrm{B}}$ \\
\hline & T3 $(10 \%)$ & $a^{5.59 \pm 0.04^{C}}$ & ${ }_{b} 5.70 \pm 0.05^{C}$ & $c^{5.85 \pm 0.05^{\mathrm{B}}}$ \\
\hline \multirow{4}{*}{$\begin{array}{l}\text { TBARS (mg } \\
\text { malonaldehyde/ kg }\end{array}$} & Control $(0 \%)$ & ${ }_{\mathrm{a}} 0.327 \pm 0.02^{\mathrm{A}}$ & ${ }_{b} 0.719 \pm 0.03^{A}$ & ${ }_{c} 0.964 \pm 0.009^{\mathrm{A}}$ \\
\hline & $\mathrm{T} 1(5 \%)$ & ${ }_{a} 0.305 \pm 0.03^{A B}$ & ${ }_{b} 0.680 \pm 0.04^{A}$ & $c 0.913 \pm 0.01^{\mathrm{AB}}$ \\
\hline & $\mathrm{T} 2(7.5 \%)$ & ${ }_{\mathrm{a}} 0.262 \pm 0.02^{\mathrm{AB}}$ & ${ }_{b} 0.653 \pm 0.03^{A}$ & ${ }_{c} 0.843 \pm 0.04^{\mathrm{BC}}$ \\
\hline & T3 $(10 \%)$ & ${ }_{a} 0.230 \pm 0.02^{B}$ & ${ }_{b} 0.620 \pm 0.03^{A}$ & ${ }_{c} 0.788 \pm 0.03^{C}$ \\
\hline
\end{tabular}

$\mathrm{n}=5$

Means with common subscripts (small letter) in a row do not differ significantly $(\mathrm{P}<0.01)$

Means with common superscripts (capital letter) in a column do not differ significantly $(\mathrm{P}<0.01)$ 
Table.5 Effect of refrigerated storage on microbiological characteristics of aerobically packaged cooked duck meat loaves (Mean \pm SE)

\begin{tabular}{|c|c|c|c|c|}
\hline \multirow[t]{2}{*}{ Parameters } & \multirow{2}{*}{ Treatments } & \multicolumn{3}{|c|}{ Storage period (Days) } \\
\hline & & 1 & 5 & 10 \\
\hline \multirow{4}{*}{$\begin{array}{l}\text { Total viable } \\
\text { Mesophilic } \\
\text { Bacterial } \\
\text { Count (log } \\
\text { cfu/g) }\end{array}$} & Control (0\%) & a $3.00 \pm 0.06^{\mathrm{C}}$ & ${ }_{b} 5.68 \pm 0.02^{C}$ & ${ }_{c} 6.61 \pm 0.02^{\mathrm{C}}$ \\
\hline & $\mathrm{T}_{1}(\mathbf{5 \%})$ & $2.81 \pm 0.08^{\mathrm{AB}}$ & ${ }_{b} 5.61 \pm 0.01^{\mathrm{AB}}$ & ${ }_{c} 6.56 \pm 0.01^{\mathrm{AB}}$ \\
\hline & $\mathrm{T}_{2}(\mathbf{7 . 5 \% )}$ & $2.63 \pm 0.09^{\mathrm{AB}}$ & ${ }_{\mathrm{b}} 5.58 \pm 0.01^{\mathrm{AB}}$ & ${ }_{c} 6.52 \pm 0.01^{\mathrm{AB}}$ \\
\hline & $T_{3}(10 \%)$ & a $2.28 \pm 0.06^{\mathrm{B}}$ & ${ }_{b} 5.51 \pm 0.01^{B}$ & ${ }_{c} 6.49 \pm 0.01^{\mathrm{B}}$ \\
\hline \multirow{4}{*}{$\begin{array}{l}\text { Total } \\
\text { Psychrophilic } \\
\text { Count (log } \\
\text { cfu/g) }\end{array}$} & Control (0\%) & $\mathrm{a} 2.04 \pm 0.01^{\mathrm{C}}$ & $\mathrm{b} 3.84 \pm 0.02^{\mathrm{C}}$ & $\mathrm{c}^{4} .88 \pm 0.02^{\mathrm{C}}$ \\
\hline & $\mathrm{T}_{1}(\mathbf{5 \%})$ & ${ }_{\mathrm{a}} 1.96 \pm 0.02^{\mathrm{AB}}$ & $\mathrm{b} 3.75 \pm 0.04^{\mathrm{AB}}$ & $4.81 \pm 0.02^{\mathrm{AB}}$ \\
\hline & $T_{2}(7.5 \%)$ & ${ }_{\mathrm{a}} 1.87 \pm 0.04^{\mathrm{AB}}$ & $\mathrm{b} 3.65 \pm 0.05^{\mathrm{AB}}$ & $c^{4} .72 \pm 0.02^{\mathrm{AB}}$ \\
\hline & $\mathrm{T}_{3}(10 \%)$ & ${ }_{\mathrm{a}} 1.72 \pm 0.05^{\mathrm{B}}$ & $\mathrm{b}^{3} .45 \pm 0.04^{\mathrm{B}}$ & $c^{4.51 \pm 0.08^{B}}$ \\
\hline \multirow{4}{*}{$\begin{array}{l}\text { Yeast and } \\
\text { Mold count } \\
\text { (log cfu/g) }\end{array}$} & Control (0\%) & ND & ND & $3.81 \pm 0.10^{\mathrm{A}}$ \\
\hline & $\mathrm{T}_{1}(5 \%)$ & ND & ND & $3.77 \pm 0.07^{\mathrm{B}}$ \\
\hline & $T_{2}(7.5 \%)$ & ND & ND & $3.50 \pm 0.08^{\mathrm{C}}$ \\
\hline & $T_{3}(10 \%)$ & ND & ND & $3.43 \pm 0.11^{\mathrm{D}}$ \\
\hline
\end{tabular}

Mean in column bearing a common superscript (capital letter) do not differ significantly $(\mathrm{P}<0.05)$

Mean in row bearing a common subscript (small letter) do not differ significantly $(\mathrm{P}<0.01)$

$\mathrm{ND}=$ Not Detected

The study revealed that yeast and mould could not be detected in any of the samples both control and treatment groups on $1^{\text {st }}$ day and $5^{\text {th }}$ day of refrigerated storage. This might be due to the inability of those organisms to grow and multiply in the refrigerated temperature. After 5 days of storage period and before the end of 10 days of storage period, growth of yeast and mould could be observed in all the samples. The organisms took a long log phase to grow. Comparatively, lower growth of yeast and mould count of duck meat loaves was recorded in treated samples. Similar observations were also recorded by Kumari et al., (2015) who studied the effect of soya and potato on shelf life of chicken meat emulsion under refrigerated condition.

On the basis of the above findings, it can be concluded that Kumura (Benincasa hispida) which occupies a strong position in the diet atlas of Assamese society can be successfully used for the production of processed ready-toeat convenient duck meat products. Considering the abundance and availability of Kumura and duck meat in Assam which forms an important part in culinary practices, there is scope to exploit the technology for commercial venture in future.

\section{References}

A.O.A.C. 1990. Official Methods of analysis of the Association Official Analytical Chemists, $15^{\text {th }}$ Edn, USDA, Washington, D.C.

Al-Snafi, A.E. 2013. The pharmacological importance of Benincasa hispida. A review. International Journal of Pharmacological Sciences and Research (IJAR), 4(12): 165-170.

American Public Health Association 1966. Standard methods for examining the dairy products. XI New York.

Bhosle, S.S.; A.K. Biswas., J. Sahoo and 
Sikka, S.S. 2011. Quality evaluation of functional chicken nuggets incorporated with ground carrot and mashed sweet potato. Food Science of Technology International, 17(3): 233239

Bratzler, L.J. 1971. Palatability factors and evaluation. In: Science of meat and meat Products. Price, J.F and and Schweiwert, B.S. (eds), Freemar, W.H and Co. San Fransisco.

Economic survey of Assam 2013. Directorate of Economics and statistics, Assam Planning and Development Department, Govt of Assam: 97

Fatariah, Z., T.Y. Tengu Zulkhairuazha and Wan Rosli, W.L. 2015. Ascorbic acid quantification in Benincasa hispida fruit extracted using different solvents. International Food Research Journal, 22(1): 208-212.

George T. G., R. Nayar and Cyriac, S. 2014. Comparison of meat quality characteristics of Vigova super $\mathrm{M}$ and kuttanad ducks. IIJR., 3(7):15-17.

Hazarika, M., S.K. Laskar and Das, A. 2014. Scope, Challenges and strategies for development of meat industry in North Eastern Region of India, Sixth conference of Indian Meat Science association and National symposium on sustainable meat production for nutritional security and consumer well being: Challenges and strategies held at DUVASU, Mathura(UP) from $28^{\text {th }}$ to $30^{\text {th }}$ November, 2014.

ICMSF 1978. Microorganisms in Food. Their significance and Method enumeration. $2^{\text {nd }}$ Edn, International Commission on Microbiological Specification for food, University of Toronto, London.

Kaur, M., A. Kumar, S. Kumar, H.R. Hakeem and Gupta, S. 2015a. Efficacy of carrot (Daucas carrota) on quality characteristics of chicken nuggets. Indian Vet. J, 92(4): 44-47
Kaur, S., S. Kumar and Bhat, J.F. $2015 b$. Effect of grape seed extract on the physic-chemical and sensory properties of chicken Nuggets. Journal of Meat Science. 11(1): 57-60

Kumari, S., J.N. Singh, S. Kumar, and Soni, K. 2015. Effect of soya and potato on shelf life of chicken meat emulsion under refrigerated condition. Journal of Meat Science. 11(1): 54-56.

Livestock census 2012. $19^{\text {th }}$ Livestock Census. All India Report, Ministry of Agriculture, Department of Animal Husbandry, Dairy and Fisheries. Krishi Bhavan, New Delhi.

Mahanta, J.D., D. Sapkota, D.C Milli, and Chakraborty, A. 2001. A survey on duck farming in Lakhimpur and Dhemaji district of Assam. Indian Vet. J. 78(6): 531-532

Mendiratta, S.K., A. S. R. Anjaneyulu, B.D. Sharma and Kondiah, N. 2008. Effect of incorporation of seasonal vegetables in emulsion based mutton products. Compendium: IMSACON3: Convention of Indian Meat Science Association and national symposium on "Safe meat for good health and environment" July 4-5 2008 of veterinary college golden Jubilee 1958-2008, Hebbal, Banglore, pp-155.

Mongale, C.W., J.A. Carpenter, and Reagan, J.O. 1985. J. Food Quality.8:145

Para, P.A. 2014. Effect of Indian Jujubee pulp on physico-chemical and sensory characteristics of chicken sausages. Journal of Meat Science and Technology, 2(4):90-94.

Pippen, E.L., D. De Fremery, H. Limeweaver and Hanson, H.L. 1965. Chicken broth flavored and pH. Poult. Sci., 44:816.

Reddy, B. O., B. Eswara Rao, E. Nagamallika, T. Srinivasa Rao and Reddy, G.V. Bhaskara. 2015. Efficacy of curry leaf powder and tomato paste on storage stability of chicken meat 
patties. Journal of Meat Science. 11(1): 43-49

Singh, O. D. 1996. A study on certain aspects of sausage prepared from duck meat. M.V.Sc. Thesis, Assam Agricultural University, Khanapara, Guwahati.

Snedecor, G.W and Cochran, W.G. 1994. Statistical Methods, $1^{\text {st }}$ Edn. East West Press Pvt Ltd, New Delhi.

Verma, A.K., V.P. Singh, and Pathak, V. 2015. Quality characteristics and storage stability of chicken meat patties incorporated with pumpkin pulp. Indian Veterinary Journal. 92(1): 37- 40

Witte, V.G.; Krause, G.F. and Barley, M.E.
(1970). A new extraction method for 2-thiobarbituric acid value for pork and beef during storage. Journal of Food Science. 35: 582-583.

Wardlaw, E.R., L.M. McCaskill and Acton, J.C 1973. Effect of postmortem muscle changes on poultry meat loaf properties, Journal of Food Science. 38:421

Zargar, F.A., S. Kumar, Z.F. Bhat, and Kumar, P. 2014. Effect of pumpkin on the quality characteristics and storage quality of aerobically packaged chicken sausages. Springer. 3: 39.

\section{How to cite this article:}

Das, J.K., M. Hazarika, A. Das, P. Gogoi, P. Hussain, D.J. Kalita and Nahardeka, N. 2019. Effect of Kumura (Benincasa hispida) on the Physico-chemical and Storage Quality Characteristics of Duck Meat Loaves. Int.J.Curr.Microbiol.App.Sci. 8(02): 2772-2783. doi: https://doi.org/10.20546/ijcmas.2019.802.325 